\title{
Artikel
}

\section{De Mededingingswet en de onderkant van de arbeidsmarkt}

\author{
Marcel Canoy en Kees Hellingman*
}

\section{Introductie}

De discussie over de groei van zzp'ers, flexwerkers, payrollers en nulurencontracters is nog lang niet verstomd. De flexibilisering van de arbeidsmarkt kan een zegen zijn als schokken op de arbeidsmarkt worden gedempt en ondernemerschap floreert. Het verhaal wordt minder florissant als achter flex verborgen werkloosheid, uitbuiting of erosie van arbeidsvoorwaarden schuilgaat. ${ }^{1}$

De sociale problemen concentreren zich aan de onderkant van de ladder, waar werkgevers vaak ruime keuze hebben en dientengevolge de onderhandelingsmacht van zzp'ers beperkt is. Vooral wanneer dienstverlening eigenlijk helemaal niet het karakter van vrij ondernemerschap heeft, maar verdacht veel lijkt op werk in loondienst, kan een zzp-constructie maatschappelijk ongewenst zijn. Zo heeft het SCP recent geconstateerd dat de hoeveelheid werkende armen stijgt en gerelateerd is aan de opkomst van zzp'ers. Nederland lijkt volgens het SCP nog niet goed te weten hoe om te gaan met deze doelgroep. ${ }^{2}$

Een in het oog springende deelverzameling van problemen aan de onderkant van de zzp-markt betreft het fenomeen van de 'gig-economy', in Nederland doorgaans angeduid met 'kluseconomie'. Hiermee worden nieuwe

Dr. M.F.M. Canoy is adviseur bij Autoriteit Consument \& Markt. Mr. K. Hellingman is specialistisch medewerker Juridische Zaken bij Autoriteit Consument \& Markt.

1. Deze passage is ontleend aan www.socialevraagstukken.nl/column/ delivergedoo/.

2. www.scp.nl/Nieuws/Aandeel_werkende_armen_in_Nederland_ gegroeid_en_overtreft_dat_van_Denemarken_en_Belgi. vormen van werken angeduid, gebaseerd op apps en online platforms.

Op dit moment is moeilijk vol te houden dat de kwetsbaarheid van deze doelgroep is ontstaan dankzij platforms, omdat het beroepen zijn die in de reguliere arbeidsmarkt ook als kwetsbaar worden beschouwd. Evenwel zijn er ook zorgen: veel van deze werkers ervaren onzekerheid over inkomsten, rechtspositie en rechten en soms is er sprake van risicovol werk. Tevens moeten relatief veel uren worden gemaakt om an een minimuminkomen te komen. Vooral als de kluseconomie groter wordt of als zou blijken dat het voor veel werkers geen kortstondige bijverdiensten zijn, verandert het beeld. ${ }^{3}$

De app- en platformmarkten gebruiken technologie om vraag en aanbod te matchen (taxivervoer, bezorgdiensten, deeleconomie, tekstschrijvers of fotografen). De technologische mogelijkheden leiden tot een verbetering van het functioneren van de markt, maar er zijn schaduwkanten. Het kan maatschappelijk ongewenst worden als een nieuwe onderklasse ontstaat. Niet alleen is deze onderklasse zelf kwetsbaar, maar de groei ervan kan ook bestaande sociale verworvenheden, zoals zijn vastgelegd in een cao, ondermijnen.

Wanneer zzp'ers bijvoorbeeld gaan gokken met hun gezondheid en daardoor 'goedkoper' worden, is het niet alleen zo dat werkgevers in de verleiding komen om steeds vaker mensen in loondienst te vervangen door zzp'ers, maar erodeert ook de onderhandelingspositie van werknemers en vakbonden bij cao-besprekingen.

In de zaak Allonby constateerde advocaat-generaal Geelhoed al in 2003 dat outsourcen van werknemers naar zelfstandigen problematisch kan zijn als deze wordt aan-

3. www.seo.nl/uploads/media/2018-30_De_opkomst_en_groei_van_de kluseconomie_in_Nederland.pdf. 
gewend 'om te ontkomen aan de consequenties van de publieke wetgeving die strekt tot bescherming van de factor arbeid of die (...) strekt tot de doorwerking van fundamentele rechtsbeginselen op de arbeidsmarkt'. ${ }^{4}$

Sociale dumping kan ontstaan als keuzes van werkgevers gevolgen hebben voor de rechtspositie van de werknemers en de (schijn)zelfstandigen, maar het is niet eenvoudig een adequate remedie te bedenken. Voor je het weet ben je of ondernemerschap aan het onderdrukken (bijvoorbeeld door gedwongen collectieve voorzieningen), de mededinging onnodig aan het aantasten (door het toelaten van horizontale prijsafspraken) of de innovatie aan het belemmeren (door het verbieden of ontmoedigen van nieuwe vormen van werken).

\section{Kerncijfers ZZP'ers en de kluseconomie}

\section{ZZP'ers}

- Nederland telt ruim 1 miljoen zzp'ers.

- Dat aantal blijft stijgen.

- Als bijverdieners meegeteld worden, ligt het aantal nog hoger.

- De groep zzp'ers is zeer divers en ze bevinden zich in allerlei sectoren en leeftijdsgroepen.

- Meerderheid is tussen de 35 en 55 jaar, voornamelijk mannen, maar de vrouwen zijn bezig met een opmars.

\section{Kluseconomie}

- Bestaat vooral uit fotografen, taxichauffeurs, vakmensen, maaltijdbezorgers en schoonmakers.

- Ongeveer 34.000 mensen, maar snel groeiend.

- Meesten doen het voor bijverdiensten (gemiddeld 11u per week) maar er zijn grote verschillen.

- Gemiddeld uurtarief € 13-15.

- In 2013 maakte 6\% van de Nederlanders gebruik van deeleconomie, in 2016 al 23\%.

- Nauwkeurige cijfers over groei kluseconomie ontbreken, de cijfers die bekend zijn tonen spectaculaire groei aan. De meeste platformen bestaan pas 5-10 jaar en kennen al vele gebruikers.

(https://www.cbs.nl/nl-nl/ dossier/dossierzzp; http://www.seo.nl/uploads/media/2018 -30_De_opkomst_en_groei_van_de_ kluseconomie_in_Nederland.pdf en https:// www.rathenau.nl/sites/default/ files/Rapport \%20Eerlijk\%20delen\%20-\%20Rathenau \%20Instituut $\% 202017 \% 20---. p d f)$

Dit artikel verkent hoe de voordelen van een flexibele arbeidsmarkt kunnen worden gecombineerd met het

4. Conclusie A-G 2 april 2003, zaak C-256/01, Allonby, ECLI:EU:C: 2003:190, punt 45 verhinderen van sociale dumping. Meer in het bijzonder gaan we in op de rol van de Mededingingswet. Het artikel is bedoeld als een bijdrage aan de actuele discussie, niet als een blauwdruk voor het beleid van de ACM of het kabinet.

Nog een disclaimer: hoewel de opening van de Nederlandse dienstenmarkt voor zzp'ers uit andere lidstaten van de EU meer impact lijkt te hebben dan het vrije werknemersverkeer ooit had en hoewel het Unierecht beperkingen oplegt aan het indammen van sociale dumping, komt de Europese context in deze bijdrage slechts zijdelings aan de orde.

We behandelen eerst de relatie tussen de Mededingingswet en zzp'ers. In de daarop volgende paragrafen gaan we in op het begrip schijnzelfstandigen en op sociale dumping. Daarna laten we zien dat het dienen van zowel de belangen van de onderkant van de arbeidsmarkt als ondernemerschap neerkomt op laveren tussen Scylla en Charibdys. In de slotparagraaf schetsen we vier verschillende situaties met onze voorkeursopties en mogelijke beleidsimplicaties.

\section{Zzp'ers en de Mededingingswet}

Eind 2007 publiceerde de NMa een Visiedocument over cao-tariefbepalingen voor zelfstandigen en de Mededingingswet. Daarin nam de NMa een tamelijk strikt standpunt in: zelfstandigen zijn ondernemingen in de zin van de mededingingsregels en zij kunnen geen beroep doen op de uitzondering op het kartelverbod die volgens Europese jurisprudentie onder bepaalde voorwaarden voor cao-afspraken geldt (de 'Albany-exceptie'). ${ }^{5}$ FNV Kunsten Informatie en Media (FNV KIEM) spande een civiele procedure aan om de onrechtmatigheid van het document te laten vaststellen, waarbij zij de casus van orkestremplaçanten naar voren bracht. De zaak legde een lange weg af, via het Hof van Justitie ${ }^{6}$ naar de einduitspraak van het Gerechtshof Den Haag, die concludeerde dat formeel gezien zelfstandige orkestremplaçanten 'schijnzelfstandigen' zijn en dat daarom 'het mededingingsrecht zich niet verzet tegen een cao-bepaling die een werkgever ertoe verplicht tegenover zelfstandige remplaçanten als bedoeld in dit arrest cao-bepalingen toe te passen en met name bepaalde (minimum)tarieven te hanteren'. ${ }^{7}$

Hoewel de uitspraak van de Europese rechter handvatten gaf voor het onderscheiden van echte zelfstandigen en schijnzelfstandigen, bleef onzekerheid bestaan over de toepassing ervan in de praktijk. De ACM zag daarin aanleiding om het Visiedocument uit 2007 in te trekken en in februari 2017 een veel korter document te publice-

5. HvJ EG 21 september 1999, zaak C-67/96, Albany, ECLI:EU:C: 1999:430.

6. HvJ EU 4 december 2014, zaak C-413/13, FNV KIEM, ECLI:EU:C: 2014:2411.

7. Gerechtshof Den Haag 1 september 2015, ECLI:NL:GHDHA:2015:2305 (FNV KIEM). 
ren dat als hulpmiddel kan dienen bij de 'self-assessment' die van marktdeelnemers verwacht wordt bij het toetsen van hun samenwerking aan artikel $6 \mathrm{Mw}$ en artikel 101 VWEU. ${ }^{8}$ In deze 'Leidraad Tariefafspraken voor zzp'ers in cao's' ${ }^{\prime}$ wordt de volgende redeneerlijn gevolgd.

- Zzp'ers die zelfstandig economische activiteiten verrichten, zijn in de regel ondernemingen.

- Tariefafspraken voor zzp'ers in een cao vallen daarom onder het kartelverbod. Zulke afspraken zijn namelijk nadelig voor de concurrentie, en voor consumenten.

- Tariefafspraken voor zzp'ers in een cao ontsnappen zelden aan het kartelverbod op grond van de algemene uitzonderingen van artikel 6 lid $3 \mathrm{Mw}$ (efficiency) en artikel $7 \mathrm{Mw}$ (bagatelvrijstelling).

- Cao-tariefafspraken voor werknemers zijn toegestaan.

- Dat is ook het geval als de werksituatie van een zzp'er vergelijkbaar is met die van een werknemer. Dan kan er sprake zijn van 'schijnzelfstandigheid'.

- Of de werksituatie van een zzp'er vergelijkbaar is met die van een werknemer, hangt vooral af van de daadwerkelijke verhoudingen op de werkvloer en van de vraag hoeveel gezag een opdrachtgever feitelijk over een zzp'er heeft.

De ACM geeft vervolgens in de leidraad suggesties mee voor naleving van de concurrentieregels bij het maken van cao-afspraken over tarieven van zzp'ers.

De ACM incorporeert hiermee de uitspraak in $F N V$ $K I E M$ in haar beleid, zonder een standpunt in te nemen over nieuwe ontwikkelingen als de opkomst van de kluseconomie en platforms en nieuwe jurisprudentie daarover buiten het mededingingsrecht. Het is verstandig voor een toezichthouder om pas guidance te geven als die gebaseerd kan worden op eigen ervaring met individuele cases en ook werkelijk duidelijkheid kan bieden.

De consequentie is echter dat de enige bruikbare route om in de praktijk aan het kartelverbod te ontsnappen vooralsnog die via de Albany-exceptie voor werknemers is, door deze tevens open te stellen voor schijnzelfstandigen. Daarmee komt veel af te hangen van de concrete toepassing van het begrip schijnzelfstandigheid: je bent zelfstandig (en dus onderneming) of je bent het niet (en dan gelijkgesteld aan een werknemer). Niet alleen moeten werkgeversorganisaties en vakbonden met het begrip werken, dat moet ook de minister van SZW, die moet beslissen over het al dan niet algemeenverbindend verklaren van cao-afspraken. ${ }^{10}$ Dan is het lastig als er niet één, eenduidig criterium is om te bepalen in welke categorie een arbeidsrelatie valt.

8. Bijv. www.acm.nl/nl/publicaties/publicatie/16979/Geen-tariefafspraken -in-caos-voor-zzpers.

9. www.acm.nl/sites/default/files/old_publication/publicaties/16978_ leidraad-tariefafspraken-voor-zzp-ers-in-cao-s-2017-02-24.pdf.

10. SZW volstaat nu qua 'handreiking' met niet meer dan een verwijzing naar de uitspraak in FNV KIEM, zie 'Cao-bepalingen over geoorloofd onderscheid en over tariefafspraken voor zzp-ers' op http://cao.minszw. nl/index.cfm?menu_item_id=16615\&rubriek_id=392840\&link_id= 38090\&hoofdmenu_item_id=16507.
In de volgende paragraaf staan we daarom eerst stil bij de vraag of het juridische onderscheid tussen echte zelfstandigen en schijnzelfstandigen voldoende duidelijk en werkbaar is. Daarna stellen we de vraag of met de introductie van het begrip schijnzelfstandige de onderliggende sociaal-economische problemen, die we in de inleiding noemden, voldoende worden ondervangen. Het eerste betreft een in hoofdzaak juridische analyse, het tweede een economische.

\section{Schijnzelfstandigheid in de rechtspraktijk}

Kan de rechter met het begrip schijnzelfstandigheid uit de voeten? Allereerst lopen we in het mededingingsrecht, het arbeidsrecht, het socialezekerheidsrecht en het fiscaal recht tegen dezelfde vraag aan - wat is de ware aard van de arbeidsrelatie? - maar elk van die rechtsgebieden werkt met eigen, onderscheiden begrippen en formuleringen. Zo waarschuwt het Gerechtshof Den Haag in de procedure van FNV KIEM dat het enkel beziet of een orkestremplaçant voor de toepassing van de Mededingingswet als onderneming of als schijnzelfstandige kwalificeert. Of zij in het laatste geval ook moeten worden beschouwd als werknemer in de zin van artikel 7:610 lid $1 \mathrm{BW}$ is in dat geding niet aan de orde. In het geval van de maaltijdbezorger van Deliveroo oordeelde de Rechtbank Amsterdam juist wel over de kwalificatie in de zin van de betreffende bepalingen uit het Burgerlijk Wetboek.

Toch menen wij dat deze zaken zich goed lenen voor een vergelijking, ook al omdat het Hof van Justitie in $F N V$ KIEM de voorliggende mededingingsrechtelijke vraag heeft beantwoord met behulp van het autonome Europese werknemersbegrip uit zijn eerdere jurisprudentie op het sociaalrechtelijke vlak (arresten Allonby, Agegate, Becu). In Allonby was al geoordeeld 'dat de kwalificatie als "zelfstandige" naar nationaal recht niet uitsluit dat een persoon moet worden aangemerkt als "werknemer" in de zin van het recht van de Unie, indien zijn zelfstandigheid slechts fictief is en dus een echte arbeidsverhouding verhult' ${ }^{11}$

\section{Orkestremplaçanten}

Het Hof van Justitie reikt in FNV KIEM verschillende criteria aan om te bepalen wanneer 'een dienstverlener zijn hoedanigheid van zelfstandige marktdeelnemer, en dus van ondernemer, kan verliezen'. Het gaat in het kort om de volgende kenmerken van schijnzelfstandigheid (geen cumulatieve vereisten):

- de zzp'er bepaalt niet zelfstandig zijn marktgedrag maar is afhankelijk van zijn opdrachtgever;

11. HvJ EU 4 december 2014, zaak C-413/13, FNV KIEM, ECLI:EU:C: 2014:2411, r.o. 35. Het Hof van Justitie gaat hiermee een stap dan in het arrest Van Delft: HvJ EU 14 oktober 2010, ECLI:EU:C:2010:610, r.o. 88 . 
- $\quad$ hij deelt niet in de financiële en commerciële risico's van de opdrachtgever;

- hij is voor de duur van de arbeidsverhouding opgenomen in de onderneming (vormt daarmee een economische eenheid);

- hij levert onder diens gezag prestaties tegen beloning (ondergeschiktheid blijft het hoofdkenmerk);

- hij beschikt niet over meer zelfstandigheid en flexibiliteit ten aanzien van het tijdschema, de plaats en de wijze van uitvoering van de toevertrouwde taken dan werknemers die hetzelfde werk doen. ${ }^{12}$

Het Gerechtshof Den Haag - dat in de verwijzingsbeschikking in de lijn van de rechtbank nog tot een ander voorlopig oordeel was gekomen - kon moeilijk om de duidelijke hint van het Hof van Justitie heen. Het zag geen wezenlijk verschil tussen de werksituatie van orkestremplaçanten met en zonder een vast dienstverband, en concludeerde voor de betreffende zzp'ers tot schijnzelfstandigheid. ${ }^{13}$

\section{Architecten}

$\mathrm{Na}$ afronding van de zaak van de orkestremplaçanten boog de ACM zich over de cao Architectenbureaus 2015-2017. Deze cao bevatte bepalingen over minimumtarieven voor 'zelfstandige professionals'. De ACM concludeerde dat het niet aannemelijk was dat ze voldeden aan de cao-exceptie. De betreffende clausule is door SZW ook niet algemeen verbindend verklaard. Een van de redenen was dat tariefbepalingen betrekking hadden op alle typen zelfstandige professionals die een architectenbureau inhuurt, zoals de functiegroepen architectuur, projectcoördinatie, ondersteuning enzovoort, en dat het onderscheid ontbrak tussen 'echte' zelfstandige professionals en zelfstandige professionals in de feitelijke werksituatie van werknemers. Kennelijk beperkten de tariefbepalingen zich niet tot medewerkers van wie de werksituatie, op het eerste gezicht, dezelfde was als die van werknemers in loondienst. Het had er de schijn van dat de architectenbureaus de bescherming van een bodemtarief niet alleen voor de onderkant van de markt zochten, maar ook voor de bovenkant.

Architecten lopen vaker tegen de beperkingen op die het mededingingsrecht hun oplegt, zoals blijkt uit de Commissiebeschikking inzake Ereloon Belgische Architecten (een regeling van de branchevereniging) ${ }^{14}$ en de inbreukprocedure die de Commissie heeft aangespannen tegen de Duitse 'Honorarordnung für Architekten und Ingenieure' (een overheidsregeling). ${ }^{15}$

12. HvJ EU 4 december 2014, zaak C-413/13, FNV KIEM, ECLI:EU:C 2014:2411, r.o. 33, 34 en 36 en de daar genoemde jurisprudentie.

13. Gerechtshof Den Haag 1 september 2015, ECLI:NL:GHDHA:2015:2305 (FNV KIEM), r.o. 2.6. Het oordeel beperkt zich tot muzikanten in hun specifieke rol als invaller bij een orkest. Daarmee is niets gezegd over de kwalificatie van muzikanten in andere werksituaties.

14. Beschikking van 24 juni 2004, http://ec.europa.eu/competition/ antitrust/cases/dec_docs/38549/38549_74_1.pdf.

15. Persberichten van de Commissie IP-15-5199 en IP-16-3646 en PbEU 2017, C 269/13 (zaak C-377/17).

\section{Maaltijdbezorgers}

Deliveroo, een digitaal platform waarop onafhankelijke restaurants online gekoppeld worden aan klanten, maakte onlangs aan haar maaltijdbezorgers in Nederland bekend dat zij na afloop van hun contracten geen arbeidsovereenkomst meer met hen zou afsluiten. In het vervolg zouden de bezorgers enkel nog als zelfstandige opdrachten vervullen, dat wil zeggen, met meer vrijheid, maar zonder de bescherming die een werknemer toekomt. Rider Sytze Ferwerda spande een (proef)procedure aan en vroeg de kantonrechter te Amsterdam voor recht te verklaren dat zijn nieuwe overeenkomst met Deliveroo geduid moet worden als een arbeidsovereenkomst in de zin van artikel 7:610 van het Burgerlijk Wetboek (BW), althans dat de bepalingen van het $\mathrm{BW}$ op de overeenkomst van toepassing zijn.

De kantonrechter wees deze vordering af. ${ }^{16} \mathrm{Bij}$ de beoordeling zocht de rechter het antwoord op twee vragen: (1) wat stond partijen bij het aangaan van de overeenkomst voor ogen (intentie), en (2) hoe hebben partijen uitvoering gegeven aan de overeenkomst? Het gaat, net zoals in de mededingingsrechtelijke beoordeling, om een 'holistische' toets, dat wil zeggen dat er niet één doorslaggevend criterium is, maar dat alle factoren en omstandigheden in hun geheel en in onderlinge samenhang moeten worden bezien.

Volgens de rechter was de uitgesproken intentie van beide partijen dat Ferwerda als zelfstandig ondernemer voor Deliveroo zou gaan werken. De termen van de (opdracht)overeenkomst weken duidelijk af van de eerdere arbeidsovereenkomst. Aan de ene kant laten zij de bezorger veel vrijheid bij de uitvoering van het werk - duidelijk meer dan bij orkestremplaçanten het geval is -, aan de andere kant ligt het risico van ziekte, verhindering en het niet bezorgen van bestellingen bij hem.

Volgens de kantonrechter is niet gebleken dat Deliveroo misbruik van omstandigheden zou hebben gemaakt

'Daarnaast kan het beroep op maatschappelijke ongelijkheid en economische afhankelijkheid, gelet op het bovenstaande, niet slagen, nu niet geconcludeerd kan worden dat [eiser] geen keuze had of niet goed wist wat hij deed toen hij de overeenkomst van 14 november 2017 met Deliveroo aanging.'

Evenals orkestremplaçanten kunnen maaltijdbezorgers voor verschillende opdrachtgevers c.q. platforms werken (geen exclusiviteit). Anders dan orkestremplaçanten kunnen zij zich laten vervangen (mits aan de veiligheidseisen is voldaan), of aangeboden werk afwijzen. Dat de tarieven niet onderhandelbaar zijn, dat Deliveroo de facturering voor zijn rekening neemt en dat het algoritme 'Frank' bezorgers die naar de maatstaven van Deliveroo goed presteren bij de inroostering bevoordeelt, levert volgens de rechter per slot van rekening geen gezagsrelatie op. Ferwerda wordt door het systeem niet 'beknot (...) in het genereren van inkomsten'. De rechter houdt rekening met het feit dat het om een bijverdienste gaat.

16. Rb. Amsterdam 23 juli 2018, ECLI:NL:RBAMS:2018:5183 (Deliveroo). 
Aan het eind van de uitspraak komt de kantonrechter nog met een opvallende overweging:

'Het moge zo zijn dat in het huidige arbeidsrecht geen rekening is gehouden met de uit de (relatief) nieuwe platformeconomie voortkomende arbeidsverhoudingen. Dat makt echter nog niet dat de onderhavige beslissing tot dusdanig onaanvaardbare resultaten leidt, dat de redelijkheid en billijkheid tot rechterlijk ingrijpen noopt. Wanneer het ongewenst wordt geacht dat werkplatforms als Deliveroo dergelijke overeenkomsten aanbieden, zal de wetgever daartegen maatregelen moeten treffen.'

Eigenlijk zegt de rechter hier twee dingen: (a) de huidige wettelijke regeling houdt geen rekening met de arbeidsverhoudingen in de nieuwe platformeconomie, en (b) gegeven de huidige wettelijke regeling vind ík het resultaat van mijn afweging billijk, maar als de wetgever hier anders over denkt, zal hij het ook anders moeten regelen. Voor dit standpunt valt begrip op te brengen, omdat de rechter nu eenmaal niet geacht wordt de billijkheid van de wet te beoordelen. Maar de overweging geeft duidelijk blijk van het ongemak van de rechter om te moeten oordelen over een situatie waarin volgens hem eigenlijk de bal bij de politiek ligt.

\section{Loodgieters}

Als het over wetgeving gaat, is het aardig zijdelings een blik te werpen op een zaak die zich in Engeland afspeelt, rond (schijn)zelfstandige loodgieters - de archetypische klussers. De Employment Rights Act kent twee categorieën: 'employee' en 'morker'. Het Supreme Court vond dat Mr Smith, een loodgieter die voor Pimlico werkte, niet in de eerste categorie viel, maar wel in de tweede. $\mathrm{Mr}$ Smith voldeed aan het criterium van 'obligation of personal performance' en was 'not a client or customer' van Pimlico. Hij kwam daarom niet in aanmerking voor de hoogste mate van bescherming, maar wel voor een zekere mate van bescherming. Ook in deze casus vertoont de rechter een balanceeract waarbij veelal dezelfde omstandigheden als in Deliveroo de revue passeren. ${ }^{17}$

\section{Taxichauffeurs (Uber)}

Een ander uitstapje voert ons naar twee zaken over Uber, waarover het Hof van Justitie onlangs oordeelde. ${ }^{18}$ Het gaat in deze zaken over de 'aard van het beestje' van Uber zelf, als de opdrachtgever van de chauffeurs. Het Hof van Justitie beschouwt een bemiddelingsdienst waarmee particuliere bestuurders, die hun eigen voertuig gebruiken, door middel van een smartphoneapp, tegen betaling in contact worden gebracht met personen die een stadstraject willen afleggen, als onlosmakelijk verbonden met een vervoerdienst en daarom moet deze worden gekwalificeerd als een 'dienst op

17. www.supremecourt.uk/cases/docs/uksc-2017-0053-judgment.pdf en www.supremecourt.uk/cases/docs/uksc-2017-0053-press-summary. pdf.

18. HvJ EU 20 december 2017, zaak C-434/15, Elite Taxi/Uber Spain, ECLI:EU:C:2017:981 en HvJ EU 10 april 2018, zaak C-320/16, Uber France, ECLI:EU:C:2018:221 het gebied van het vervoer'. De uitspraken brengen mee dat Uber zich niet kan onttrekken aan de nationale regulering (bijvoorbeeld een vergunningplicht) op het gebied van taxivervoer. In zoverre is geen sprake van een 'wettelijk vacuüm' waarin zij opereert. De opvatting dat Uber niets meer is dan een digitaal platform, is hiermee verworpen.

\section{Balans}

Wat kunnen we opmaken uit de hierboven besproken zaken? In de rechtspraak zijn criteria ontwikkeld om de arbeidsrelatie van geval tot geval te duiden als hetzij zelfstandige dienstverlening, hetzij arbeid in ondergeschiktheid. Met de motivering in individuele gevallen waarom orkestremplaçanten niet en maaltijdbezorgers daarentegen wel 'zelfstandigen' zijn, lijkt op het eerste gezicht niet veel mis. Toch is het de vraag of deze casuistische benadering wel de juiste is. Deze zal aanleiding geven tot steeds nieuwe procedures over verschillende arbeidsrelaties, waarmee pas op langere termijn zekerheid wordt verkregen. Men zou nog kunnen tegenwerpen dat de uitkomst na een aantal rechterlijke uitspraken wel voorspelbaar genoeg is, zodat nieuwe procedures na verloop van tijd niet meer nodig zijn. Maar dat stadium is beslist nog niet in zicht. De uitspraken over orkestremplaçanten en maaltijdbezorgers geven nauwelijks zekerheid over hoe de afweging zal uitpakken in het geval van, bijvoorbeeld, Uberchauffeurs, fotografen, schoonmakers of wijkverpleegkundigen. Nieuwe procedures zullen bovendien betrekking hebben op verschillende rechtsgebieden en gevoerd worden bij verschillende rechters, met een grote kans op divergentie in plaats van de wenselijke convergentie.

Een andere vraag brengt ons terug bij het eigenlijke thema van deze bijdrage: wordt met de uitspraken over (schijn)zelfstandigheid wel recht gedaan aan de onderliggende sociaal-economische problemen? Of zijn er andere routes binnen en buiten het mededingingsrecht denkbaar die beter aansluiten bij de behoefte aan een flexibeler inzet van arbeid met behoud van een redelijke mate van sociale bescherming? Daartoe trachten we in de volgende paragrafen scherper in beeld te krijgen wat in economische zin het probleem is en welke (alternatieve) oplossingen, met hun voor- en nadelen, denkbaar zijn.

\section{Sociale dumping}

Wie heel goed aanvoelde wat het onderliggende sociaaleconomische probleem is, was advocaat-generaal Wahl in de zaak van $F N V$ KIEM. ${ }^{19}$ Hem stond daarom een andere benadering voor ogen dan mededingingsautoriteiten gewend waren.

Het probleem dat hij waarnam, was dat van 'sociale dumping'. De sterke groei van zelfstandigen kan het verworven niveau van sociale bescherming voor de werECLI:EU:C:2014:2215 
kenden ondergraven. Hij stelde voor om de Albanyexceptie langs die lijn toe te passen. Wanneer een vakbond onderhandelt namens en in het belang van werknemers, is aan het aardvereiste voor toepasselijkheid van de exceptie voldaan. Bovendien is aan het doelvereiste voldaan, indien cao-bepalingen beogen om sociale dumping te voorkomen. $\mathrm{Zij}$ dragen dan rechtstreeks bij aan de verbetering van arbeidsvoorwaarden of werkgelegenheid van werknemers. De dreiging dat werknemers door goedkopere zelfstandigen worden vervangen, tast immers het grote belang van werknemers bij een stabiele dienstbetrekking aan, en bemoeilijkt bovendien de collectieve onderhandelingen over verbetering van lonen.

Door het Hof van Justitie is het tegengaan van sociale dumping in de sfeer van het vrije verkeer als 'dwingende reden van algemeen belang' erkend, ter rechtvaardiging van zowel nationale wetgeving als collectieve acties. ${ }^{20} \mathrm{En}$ de EU-wetgever heeft dit doel op een aantal terreinen (zoals uitzendwerk) al in een regeling vervat. De nationale rechter moet volgens de advocaat-generaal wel nagaan of er in de betreffende sector een 'reëel en ernstig gevaar van sociale dumping' bestaat en zo ja, of de betrokken bepalingen noodzakelijk zijn om die dumping te voorkomen. In de tweede plaats moet hij nagaan of de bepalingen qua werkingssfeer en draagwijdte niet verder gaan dan nodig is om de doelstelling van voorkoming van sociale dumping te verwezenlijken. Hiermee oppert de advocaat-generaal de introductie van een evenredigheidstoets à la de uitzondering op het vrije verkeer, die de oorspronkelijke Albany-exceptie niet kent.

Het Hof van Justitie is de advocaat-generaal in $F N V$ KIEM niet gevolgd. Het is gissen, maar wij kunnen ons voorstellen dat het Hof van Justitie de nationale rechter niet heeft willen opzadelen met een oordeel over het brede maatschappelijke vraagstuk van sociale dumping en de uitkomst van de procedure liever heeft laten afhangen van een oordeel over de concrete betrekking in het geding, tussen remplaçant en orkest.

In verschillende sectoren kan sprake zijn van verdringing van werkenden in loondienst door zzp'ers en daarmee van een erosie van arbeidsvoorwaarden en het ondergraven van de sociale bescherming van de eerste groep. Maar het kan ook gaan om een nieuwe markt, die ontsloten wordt door het benutten van de digitale techniek en nieuwe ondernemingsvormen als platforms. Bij postbezorgers is typisch sprake van verdringing en ondermijning. Bij maaltijdbezorgers is eerder sprake van een opkomende (groei)markt.

Laten we de draad oppakken bij de redeneerlijn van de Leidraad van de ACM (paragraaf 2). Wij cursiveerden daar het zinnetje 'Zulke [tarief]afspraken zijn namelijk nadelig voor de concurrentie, en voor consumenten'. Deze veronderstelling is vatbaar voor discussie. In normale markten is het maken van tariefafspraken inderdaad nadelig voor consumenten. Ook zzp'ers kunnen door

20. HvJ EU 19 december 2012, zaak C-577/10, Commissie/België, ECLI:EU:C:2012:814, r.o. 45; HvJ EG 12 oktober 2004, zaak C-60/03, Wolff \& Müller, ECLI:EU:C:2004:610, punt 41; en HvJ EG 18 december 2007, zaak C-341/05, Laval un Partneri, ECLI:EU:C:2007:809, r.o. 103 en daar aangehaalde rechtspraak. prijsconcurrentie zichzelf van hun concurrenten onderscheiden. De vraag is echter of dit altijd opgaat.

De onderkant van de arbeidsmarkt wordt in toenemende mate gekenmerkt door macht van ondernemers uitgeoefend via zelfstandigen. ${ }^{21}$ Deze en andere ontwikkelingen maken dat de onderliggende veronderstelling (dat de arbeidsmarkt een goed functionerende markt is) aan herziening of op zijn minst kwalificatie onderhevig is.

In onze visie ontstaat het probleem wanneer een sector gekenmerkt wordt door een combinatie van sociale dumping en monopsonie. Het uitgangspunt van de ACM is dat inkoopmacht van een individuele onderneming alleen een probleem vormt als het stroomafwaarts gepaard gaat met verkoopmacht. ${ }^{22}$ Anders profiteren de consumenten van inkoopmacht. Die redeneertrant is op zich juist, maar veronderstelt in ons geval een goed werkende arbeidsmarkt. Net zoals het niet maatschappelijk gewenst is als 10-jarige kinderen uit Bangladesh onze kleren maken (goedkoop!), is het ongewenst als monopsonie gepaard gaat met sociale dumping.

\section{Tussen Scylla en Charybdis}

In de voorgaande paragraaf is betoogd dat er een probleem aan de onderkant van de arbeidsmarkt is ontstaan en dat de Mededingingswet niet vanzelfsprekend is uitgerust om met dat probleem overweg te kunnen.

De Mededingingswet kent natuurlijk wel uitzonderingen op het kartelverbod. Als de afspraken zich beperken tot een klein groepje of als er aantoonbare voordelen voor consumenten zijn, kunnen partijen onderling afspraken maken. Deze mogelijkheid heeft ertoe geleid dat er regelmatig gepleit wordt voor het maken van prijsafspraken voor zzp'ers. ${ }^{23}$

Het toestaan van horizontale prijsafspraken voor zzp'ers leidt echter tot een aaneenschakeling van problemen. ${ }^{24}$ Zo verhogen prijsafspraken de prijzen voor consumenten. Het kan ook leiden tot minder productie of teruglopende kwaliteit. Tot slot worden beroepen waar een overschot aan is, kunstmatig in stand gehouden. Voor échte zzp'ers geldt daarom dat bij het toelaten van horizontale prijsafspraken, het middel erger wordt dan de kwaal.

21. E. Benmelech, N. Bergman en H. Kim, Strong Employers and Weak Employees: How Does Employer Concentration Affect Wages?, NBER Working Papers 2018, nr. 24307; J. Azar, I. Marinescu en M.I. Steinbaum, Labor Market Concentration, NBER Working Papers 2017, nr. 24147.

22. www.acm.nl/nl/publicaties/publicatie/7084/Individueel-en-collectiefonderhandelen-zelfstandig-externe-zorgaanbieders-en-verzekeraars. Dit impliceert niet dat inkoopkartels zonder meer zijn toegestaan, zie bijv. Beschikking van de Commissie van 8 februari 2017 (AT.40018 - Car battery recycling), http://ec.europa.eu/competition/antitrust/cases/dec docs/40018/40018_2611_3.pdf en http://ec.europa.eu/competition/ antitrust/cases/dec_docs/40018/40018_2612_3.pdf.

23. https://nos.nl/artikel/2160454-vakbonden-tariefafspraak-voor-zzp'ermoet-kunnen.html.

24. Deze passage is ontleend aan https://fd.nl/cookiewall?target= $\% 2$ Fopinie \%2F1176561\%2Fversoepeling-van-mededingingswet-voorzelfstandigen-is-geen-goed-idee. 
Door genoemde problemen en de algehele context van het belang van ondernemerschap, zou men geneigd kunnen zijn hier een liberaal standpunt over in te nemen. Waarom oordelen over de wenselijkheid van pakweg het ondernemerschap van de maaltijdbezorgers van Deliveroo? Laten we het maar een jaartje of wat aankijken. Misschien blijkt dan dat het ondernemerschap best een goed idee was, de bezorgers tevreden zijn, concurrenten dit businessmodel gaan volgen en iedereen beter af is.

Deze liberale houding is prima te verdedigen in veel arbeidsmarkten. Het is doorgaans niet verstandig wanneer de wetgever of de mededingingsautoriteit creatieve concepten in de kiem gaan smoren. De vraag is waar de grens bereikt wordt van de wenselijkheid van experimenten. Wanneer de objecten van de experimenten kwetsbare groepen zijn en eventuele negatieve gevolgen gedragen worden door die kwetsbare groepen, komt het liberale standpunt onder druk te staan.

Deze druk is niet alleen een morele kwestie: wat zijn wij bereid te accepteren in termen van sociale ongelijkheid of rechtvaardigheid? Het is ook in het langetermijnbelang van een land wanneer arbeidsverhoudingen goed zijn en arbeidsrechten worden gerespecteerd.

Het IMF constateerde vorig jaar al dat er een trend gaande is, waarbij arbeid het aflegt tegen kapitaal in termen van verdeling. ${ }^{25}$ Dat geldt in het bijzonder in ons land waar al jaren de werknemers disproportioneel weinig overhouden van de welvaartsstijgingen. ${ }^{26}$ Op zowel economische als morele gronden is daarom de vraag gerechtvaardigd wat de juiste weg is om kwetsbare arbeiders aan de onderkant te beschermen.

De tekortkomingen van het liberale standpunt leiden niet zelden tot vergaande voorstellen om de overheid in te schakelen of de Mededingingswet uit te schakelen. Zo zijn er periodieke pleidooien voor het verplichtstellen van sociale voorzieningen zoals arbeidsongeschiktheidsverzekering en pensioenen, of legt de overheid partijen (zoals bij postbezorging) quota op van vaste werknemers. Zulke voorstellen leiden vaak weer tot andere problemen. De quota kennen nadelen in het reduceren van flexibiliteit en de hoogte van de quota is arbitrair. Verplichte voorzieningen kennen als nadeel dat er vaak ook groepen zelfstandigen in worden betrokken voor wie deze verplichtingen helemaal niet wenselijk zijn (een vorm van paternalisme). Om zowel de belangen van de onderkant van de arbeidsmarkt als het vrije ondernemerschap te dienen vereist daarom dat men laveert tussen Scylla en Charybdis.

Een eerste aangrijpingspunt zou kunnen zijn om anders te gaan kijken naar het onderscheid tussen werknemers en zelfstandigen, zoals ook hiervoor is geanalyseerd. Schiek en Gideon $\left(2018^{27}\right)$ suggereren om een criterium

25. www.imf.org/en/Publications/WEO/Issues/2017/04/04/worldeconomic-outlook-april-2017.

26. www.dnb.nl/nieuws/nieuwsoverzicht-en-archief/DNBulletin2018/ dnb372062.jsp.

27. D. Schiek en A. Gideon, 'Outsmarting the gig-economy through collective bargaining - EU competition law as a barrier to smart cities?', https://pure.qub.ac.uk/portal/en/publications/outsmarting-the- toe te voegen aan de Albany-exceptie. De eerste conditie van de Albany-exceptie luidt dat collectieve overeenkomsten buiten de Mededingingswet vallen wanneer zij het resultaat zijn van onderhandelingen tussen organisaties die werkgevers en werknemers vertegenwoordigen. Een op het oog kleine, maar belangrijke stap zou zijn de categorie 'werknemers' te verruimen tot 'werkenden'. In FNV KIEM zette het Hof van Justitie deze stap nog niet. $^{28}$

De rechter in FNV KIEM oordeelde al wel dat - consistent met eerdere uitspraken - een arbeider niet het commerciële risico van een werkgever mag lopen. De essentie van het inhuren van een zelfstandige in plaats van een werknemer is dat die zelfstandige wel een eigen commercieel risico loopt. Dat geldt voor het inhuren van zelfstandigen net als voor andere vormen van uitbesteden. Een bedrijf kan bijvoorbeeld de schoonmaak of catering uitbesteden aan een commerciële partij die dan ook logischerwijze het commerciële risico van die activiteiten loopt.

Maar als grote bedrijven met onderhandelingsmacht (zoals Uber) hun eigen normale commerciële risico's zouden overhevelen naar kwetsbare zelfstandigen kun je vraagtekens plaatsen bij de logica daarvan. Een economisch logische notie van werk maakt een onderscheid tussen een overheveling van risico gedreven door het benutten van kwetsbaarheden of het benutten van ondernemerschap. Bij schoonmaak of catering is er keuze aan twee kanten en creëert ondernemerschap vaak waarde. Maar bij Deliveroo-riders of Uber-chauffeurs is dat minder vanzelfsprekend. De notie van arbeiders zou dus expliciet gekoppeld moeten worden aan de redelijkheid van het risico wat de arbeider loopt. Vanzelfsprekend is dit juridisch nog geen gelopen race, maar het zou bij het ' $g i g$ ' deel van het probleem een oplossing kunnen bieden.

Een manier om tussen Scylla en Charybdis te laveren is om met minimumtarieven te werken, zoals ook voorgesteld door Schiek en Gideon (2018) alsook door Grosheide en Barenberg (2016). ${ }^{29}$ Een minimumtarief is een compromis tussen bescherming en vrijheid (je kunt immers ook hogere tarieven dan het minimum vragen) en vormt daarmee een minder grote inbreuk op ondernemerschap dan horizontale prijsafspraken.

Vaak worden minimumtarieven op één hoop gegooid met andere vormen van prijsafspraken. Veel zaken over minimumtarieven (bijvoorbeeld in het Verenigd Koninkrijk) ${ }^{30}$ gaan over varianten van verticale prijsbinding (Resale Price Maintenance, RPM), waarbij minimumtarieven gebruikt worden als een manier om de mededinging te beperken.

gigeconomy-through-collective-bargaining--eu-competition-law-as-abarrier-to-smart-cities(de12a628-cb05-47ac-94cf-085c59c22427).html.

28. HvJ EU 4 december 2014, zaak C-413/13, FNV KIEM, ECLI:EU:C: 2014:2411, r.o. 28-30.

29. E. Grosheide en M. Barenberg, 'Minimum fees for the self-employed: a European response to the 'Uber-ized' economy?', The Columbia Journal of European Law 2016, nr. 2, https://dare.uva.nl/search?identifier= 137a973d-5fdf-4962-a26f-ec06aeed6ef5

30. www.gov.uk/government/case-studies/resale-price-maintenance-casestudies. 
In de economische theorie is er buiten RPM nauwelijks aandacht voor minimumprijzen, behalve in standaardtekstboeken waarbij de baten (bijvoorbeeld bescherming van werknemers) worden afgezet tegen bekende nadelen (overproductie, hogere prijzen voor consumenten).

Hoewel sommige argumenten tegen het maken van prijsafspraken in goederen- en dienstenmarkten ook gelden voor de arbeidsmarkt, staan daar mogelijk ook baten tegenover in de vorm van bescherming van kwetsbare arbeid. Bij het formuleren van minimumtarieven voor zzp'ers aan de onderkant van de arbeidsmarkt zal daarom altijd een belangenafweging moeten gemaakt worden en een onderbouwing waarom in de specifieke markt een minimumtarief een proportioneel instrument is. Overigens ligt een dergelijke belangenafweging al ten grondslag aan het stelsel van cao's (en het instrument van algemeenverbindendverklaring), dat vooral voor de onderkant van de arbeidsmarkt van belang is. Het is goed om nog eens terug te halen wat advocaat-generaal Wahl in de zaak FNV Kiem hierover zegt. ${ }^{31}$

'Ik ben (...) van mening dat de bevordering van de sociale vrede en de totstandbrenging van een stelsel van sociale bescherming dat voor alle burgers billijk is, uiterst belangrijke doelstellingen zijn in elke moderne maatschappij. De zaken liggen echter anders wanneer het gaat om overeenkomsten die tot doel of tot gevolg hebben de concurrentie tussen ondernemingen te beperken of uit te schakelen.'

Vervolgens legt Wahl uit dat prijsconcurrentie voor zelfstandigen een groot goed is en dat minimumtarieven voor zelfstandigen daarom ook altijd als een als 'ernstige vorm van mededingingsbeperking' zijn gezien (punt 36). Wahl constateert dan: 'De reden voor het door de opstellers van de Verdragen gemaakte onderscheid tussen werknemers en zelfstandigen is vrij eenvoudig: de wijze waarop de beroepsactiviteiten van deze twee groepen worden georganiseerd en uitgeoefend, verschilt als regel sterk.' (punt 43).

De cruciale verschillen tussen zelfstandigen en werknemers (die betrekking hebben op gezagsverhouding, commerciële vrijheden en risico's) zijn onmiskenbaar bij grote groepen zelfstandigen, maar minder bij zelfstandigen aan de onderkant van de arbeidsmarkt. Juist bij die groepen vervaagt het onderscheid, kan sprake zijn van schijnzelfstandigheid, worden risico's die normaal bij opdrachtgevers horen bij zelfstandigen neergelegd en is hun onderhandelingspositie heel slecht.

Om deze redenen concludeert advocaat-generaal Wahl dan ook dat werknemers onder die omstandigheden hun vermogen en prikkel om collectieve onderhandelingen met werkgevers te voeren ernstig zien verzwakken. Wahl vindt daarom het voorkómen van sociale dumping een doel dat legitiem kan worden nagestreefd door een collectieve overeenkomst ook in relatie met zelfstandigen. Wij delen deze inschattingen van Wahl.

31. Conclusie A-G 11 september 2014, zaak C-413/13, FNV KIEM, ECLI:EU:C:2014:2215
Er kleven echter ook nadelen aan het zetten van minimumtarieven voor zelfstandigen, deels ook genoemd door advocaat-generaal Wahl:

- Heterogeniteit. Sommige groepen zelfstandigen zijn moeilijk onder één noemer te scharen. Voor zover dat te maken heeft met kwaliteitsverschillen is dat helemaal niet erg (voor de hogere kwaliteit is het minimumtarief dan niet bindend), maar voor 'horizontale' verschillen (productdifferentiatie) is het wel lastig, omdat het niet duidelijk is waarop het minimumtarief dan betrekking heeft.

- Te hoge tarieven of collusie. Uiteraard is er altijd een uitruil tussen het gevaar van sociale dumping en het consumentenbelang van lage tarieven. We zien hier geen bijzonder nadeel, omdat de afweging tussen deze belangen al onderdeel is van de onderbouwing van de minimumtarieven of onder de Mededingingswet vallen.

- Te brede toepassing. Hetzelfde geldt voor een te brede toepassing. Advocaat-generaal Wahl zegt daarover dat hij huiverig is wanneer vakverenigingen met een beperkte vertegenwoordiging collectieve overeenkomsten sluiten die de werkgevers jegens alle zelfstandigen binden. Het feit dat er zelfstandigen zijn met een positie die economisch vergelijkbaar is met die van werknemers, rechtvaardigt volgens Wahl geen volledige en a-priorigelijkstelling van de twee categorieën. Ook dit maakt onderdeel uit van de onderbouwing en vormt daarom volgens ons geen apart obstakel.

- Obsolete beroepen. Het zetten van minimumtarieven voor zelfstandigen aan de onderkant van de arbeidsmarkt kan als neveneffect hebben dat er beroepsgroepen kunstmatig in leven worden gehouden die beter een 'natuurlijke dood kunnen sterven', om het wat cru te formuleren. Ook voor dit bezwaar geldt dat een onderbouwing van sociale dumping dit mee moet nemen en het daarmee geen apart obstakel vormt.

- Dumping via gewerkte uren (in plaats van tarieven). Deze manier om minimumtarieven te omzeilen kan in de praktijk een reëel obstakel vormen.

Niettemin kunnen minimumtarieven voor zelfstandigen, mits goed onderbouwd, een legitiem publiek belang dienen, al zijn er ook andere routes beschikbaar.

\section{Conclusie en reflectie}

In een recente brief aan de Kamer concluderen bewindspersonen Koolmees en Snel dat ze meer onderzoek willen naar de manier waarop zzp'ers hun tarief bepalen; het kabinet wil ook de Europese Commissie hierbij betrekken. Ook gaat het kabinet verder met de uitwerking van maatregelen voor de boven- en de onderkant van de arbeidsmarkt en benoemt het een onafhankelijke commissie die onderzoek doet naar 
vraagstukken gerelateerd aan de 'moderne' arbeidsmarkt.

Onze beschouwingen monden uit in een taxonomie van markten waar zelfstandigen aan de onderkant van de arbeidsmarkt op opereren. De - in onze ogen - beste oplossing hangt af van in welk geval we zitten.

1. Orkestremplaçanten: schijnzelfstandigen In gevallen waar aangetoond kan worden dat er sprake is van schijnzelfstandigheid is de jurisprudentie na $F N V$ KIEM helder: de schijnzelfstandigen vallen ook onder de cao. De beleidsimplicatie is hier het handhaven van de status quo.

\section{Deliveroo: zelfstandigen concurreren met} werknemers

Er zijn ook markten waar de zelfstandigen 'echt' zijn, concurreren met werknemers en de arbeidsvoorwaarden van die werknemers mogelijk ondermijnen. De casus van Deliveroo is typerend. De rechter heeft geoordeeld dat er geen sprake is van schijnzelfstandigheid. Of er sprake is van sociale dumping staat echter niet vast. Het zou kunnen, maar de markt is nog jong en er is mede daarom nog onvoldoende bekend om dat te kunnen beoordelen. Daarnaast zijn de riders vaak jongeren die de baan als bijbaantje nemen en juist aan de flexibiliteit hechten die zelfstandigen genieten. De beleidsimplicatie is hier dat bij deze gevallen het zaak is de markt de tijd en ruimte te geven om te bepalen welke kant het kwartje opvalt.

\section{Platforms: zelfstandigen concurreren niet} met werknemers maar gaan prijsdumpen

Deze casus is de spiegel van de vorige. Er is nu wel prijsdumping maar geen concurrentie met werknemers die onder een cao vallen. Platforms fungeren hier vaak als matchmaker tussen vraag en aanbod (bijvoorbeeld voor klussers, vertalers of schoonmakers). Er kunnen dan situaties ontstaan waarbij zelfstandigen hun diensten aanbieden voor tarieven die maatschappelijk ongewenst kunnen zijn. De beleidsimplicatie hangt van de situatie af, want er zijn twee verschillende oplossingen hiervoor. Ten eerste het 'Deense model'. ${ }^{32}$ Mensen die hun diensten aanbieden als zelfstandigen voor schoonmaakwerk op het online platform Hilfr vallen onder een cao en de werkgever stelt ze in staat om na 100 uur zelf te bepalen of ze liever weer zelfstandig willen worden. Het Deense model gaat uit van vrijwilligheid. Als het platform niet bereid is om zelfstandigen tegen prijsdumping te beschermen, dan kan de overheid minimumtarieven bij wet regelen.

Een wettelijk minimumtarief dient wel de Europese regels en jurisprudentie met betrekking tot het vrije dienstenverkeer en vrije vestiging in acht te nemen. Kortweg: de minimumtarieven discrimineren niet naar nationaliteit of verblijfplaats (en vormen ook geen verkapte beperking van het vrije verkeer), zijn geschikt en noodzakelijk en gaan niet verder dan nodig is voor het

32. www.equaltimes.org/in-denmark-a-historic-collective?lang=en\#. W5Y0I_5IJGE. bereiken van het legitieme doel van sociale bescherming. ${ }^{33}$ De Dienstenrichtlijn voorziet - aanvullend op de verdragsbepalingen - in het wegnemen van handelsbelemmeringen door het vereenvoudigen van administratieve procedures voor dienstverleners, het versterken van de rechten van consumenten en bedrijven, en het aanmoedigen van samenwerking tussen EU-landen. De richtlijn beoogt echter niet in de weg te staan aan initiatieven van de EU of maatregelen van de lidstaten ter verbetering van de sociale bescherming. ${ }^{34}$

Stelt de overheid minimumtarieven vast op initiatief van de kant van particuliere ondernemingen of ondernemersorganisaties, dan gelden de condities van de Europese rechtspraak Arduino en Cipollo: de overheid toetst aan het algemeen belang en behoudt eindverantwoordelijkheid. ${ }^{35}$ Zodra er een te grote mate van invloed is van de kant van de beroepsgroep, zijn de mededingingsregels alsnog van toepassing en kan de maatregel van de overheid in strijd komen met het beginsel dat zo'n maatregel het nuttig effect aan de mededingingsregels voor ondernemingen niet mag ontnemen. ${ }^{36}$

Bij schrijvers en vertalers bestaat een dergelijke wettelijke regeling al. ${ }^{37}$ In feite gaan de huidige kabinetsplannen ervan uit dat de overheid een soort minimumloon kan vaststellen voor alle werkers, werknemers en zelfstandigen. Een nadeel van deze route is dat ze nogal statisch is. De veranderingen gaan snel in de kluseconomie. Voor je het weet leg je iets in wetgeving vast met de wijsheid van vandaag terwijl we morgen in een heel andere wereld leven.

\section{Uber: zelfstandigen ondermijnen} arbeidsvoorwaarden werknemers

Er zijn ook markten waar de zelfstandigheden 'echt' zijn, concurreren met werknemers én de arbeidsvoorwaarden van die werknemers ondermijnen. We hebben dat hiervoor de vorm 'Uber' genoemd, omdat de casus van de taxivervoerder in dit verband vaak genoemd wordt. ${ }^{38}$ De beleidsimplicatie hier is dat het Hof van Justitie kan toestaan dat er organisaties zijn die minimumtarieven kunnen zetten tegelijk voor zowel zzp'ers

33. Voor jurisprudentieoverzichten op het gebied van vrije dienstenverkeer en vrije vestiging, zie https://ec.europa.eu/docsroom/documents/ 22543/attachments/1/translations/en/renditions/pdf en https://ec. europa.eu/docsroom/documents/16743/attachments/1/translations/ en/renditions/pdf.

34. Richtlijn 2006/123/EG van 12 december 2006 betreffende diensten op de interne markt, PbEU 2006, L 376/36; zie considerans, overwegingen 14, 40, 86 en 87. Zie ook reeds Richtlijn 96/71/EG van 16 december 1996 betreffende de terbeschikkingstelling van werknemers met het oog op het verrichten van diensten.

35. HvJ EG 19 februari 2002, zaak C-35/99, Arduino, ECLI:EU:C:2002:97 en HvJ EG 5 december 2006, gevoegde zaken C-94/04 en C-202/04, Cipolla, ECLI:EU:C:2006:758.

36. Arrest Arduino, r.o. 35 en de daar aangehaalde rechtspraak.

37. Art. $25 \mathrm{c}$ en $25 \mathrm{~d}$ Auteurswet. Hoofdstuk IA Auteurswet is ingevoegd bij de Wet Auteurscontractenrecht, van 30 juni 2015, Stb. 2015, 257, om de positie van makers en uitvoerende kunstenaars ten opzichte van exploitanten te versterken.

38. We hebben op zich geen bewijs verzameld waaruit blijkt dat dit het geval is. Maar in België moet Uber aan minimumtarieven voldoen die door de overheid zijn vastgesteld om sociale dumping tegen te gaan. Zie www.standaard.be/cnt/dmf20180201_03333706. 
als werknemers. Deze optie is 'moderner' in de zin dat het soms (zeker aan de onderkant van de arbeidsmarkt) kunstmatige en deels achterhaalde strikte onderscheid tussen werknemers en zzp'ers erdoor verdwijnt. De relatie met sociale dumping wordt hierdoor meer expliciet gelegd dan in de andere opties. Grosheide en Barenberg $^{39}$ zien aanknopingspunten met uitspraken in de Verenigde Staten en in de uitspraken rond de zaak $F N V$ Kiem. De hiervoor (bij voetnoot 28) aangehaalde overwegingen van het Hof van Justitie komen erop neer dat een vakbond die namens zelfstandigen onderhandelt daarmee de facto een ondernemersvereniging is (en daarmee niet de status van sociale partner kan hebben). Maar gemeenschappelijke belangenbehartiging en onderhandelingen door een organisatie (bijvoorbeeld een ad-hocorganisatie met vertegenwoordiging van zowel vakbond als zzp-belangenbehartigers) zijn daarmee wellicht nog niet uitgesloten. Het zou helpen als de begrippen 'sociale partners' en 'sociale dialoog' in artikel 152 VWEU een zodanig ruimere inhoud zouden krijgen, waarbij de Uniewetgever mogelijk een rol kan spelen.

Wij realiseren ons dat het vinden van een goede balans bij het zetten van minimumtarieven niet eenvoudig is. Als de overheid ze voorschrijft (zoals hierboven in geval 3, maar het zou ook in de andere gevallen kunnen), moet zij het vrije dienstenverkeer respecteren. ${ }^{40}$ 'Echte' zelfstandigen zijn ondernemingen in de zin van de Mededingingswet en stuiten daarom zoals we hebben gezien op het kartelverbod als zij het zelf regelen, of als zij een rol spelen in collectieve onderhandelingen. In beide gevallen is het zoeken naar 'uitzonderingen op de regel'. Maar waar een wil is, is een weg.

Ondanks de nadelen zien wij bij casus 3 en vooral bij casus 4 het zetten van minimumtarieven als een interessante verbetering ten opzichte van de huidige situatie. Mits goed onderbouwd kan de schade in termen van het beperken van concurrentie aan de onderkant van de arbeidsmarkt relatief klein zijn, maar is de sociale winst potentieel groot. In die gevallen doet het invoeren van minimumtarieven recht aan het vervagende onderscheid tussen werknemers en zelfstandigen aan de onderkant van de arbeidsmarkt en draagt het bij aan een rechtvaardige arbeidsmarkt. 